\title{
ÇANAKKALE CEPHESI'’NDE SU TEMINI VE TEMIZLIK HIZMETLERI
}

\author{
Yavuz Selim ÇELOĞLU*
}

\begin{abstract}
$\ddot{O} \mathbf{z}$
Muharebelerin cereyan ettiği Gelibolu yarımadası temiz su kaynakları bakımından pek de zengin sayılmazdı. Dolayısıyla ordunun su ihtiyacını karşılamak hususunda bazı zorluklarla karşı karşıya kalacağı aşikârdı. Aslında muharebe sahası denizle iç içe olduğundan deniz suyundan istifade edilerek ordunun içme ve kullanım suyu ihtiyacı karşılanabilirdi. Osmanlı Devleti, deniz suyunu arıtacak teknolojiye sahip olmadığı gibi zamanında deniz suyunu harp sahasına ulaştıracak bir isale hattı da kurulamadığından muharebe sahasının hemen gerisinde bulunan deniz suyundan istifade edilemedi. Bu bakımdan gerek ordunun içme suyu ihtiyacı gerekse erlerin temizlik ve diğer hizmetleri için gerekli olan su, muharebe sahasında bulunan pınar, çeşme, kuyu ve derelerden karşılandı. Bu su kaynaklarının önemli bir kısmı ise havaların 1sınmaya başlamasıyla kurumaya yüz tuttuğundan ordu, bu aylarda su temini hususunda büyük sıkıntı yaşamıştır. Bu çalışmada, Çanakkale Muharebeleri esnasında Türk ordusunun içme suyuna ulaşma imkânı ele alınmıştır. Bununla birlikte erlerin beden, elbise ve çevre temizliği ile bu hususta alınan tedbirler üzerinde durulmuştur. Böylece askerî lojistiğin bir unsurunu oluşturan bu hizmetlerin, Türk ordusunun kazandığı büyük zafere tesiri ortaya konulmaya çalışılmıştır.
\end{abstract}

Anahtar Kelimeler: Çanakkale Muharebeleri, Türk ordusu, su temini, temizlik

\section{Abstract \\ Water Supplies and Cleaning Services on the Çanakkale Front}

The Gallipoli Peninsula, where battles took place, were not rich in terms of clear water resources. Therefore, it was obvious that the army would face challenges meeting their need for water. The army's need for potable and service water could be met by using sea water because the battlefield was very close to sea. However, the sea water just behind the battlefield could not be used because the Ottoman Empire did not have the technology to purify sea water and could not establish pipelines to convey sea water to the battlefield. Therefore, water used to supply the army needs for soldiers to drink and to clean themselves, as well as for other service needs, had to be provided by springs, fountains, water wells, and streams on the battlefield. The army faced serious challenges regarding water supply on hot months because most of these water resources tended to dry up as

* Dr., Bingöl Üniversitesi, Fen-Edebiyat Fakültesi, Tarih Bölümü, Bingöl.

E-posta: ys_celoğlu@hotmail.com. ORCID: 0000-0002-7962-2982

(Makale Gönderim Tarihi: 27.05.2021 - Makale Kabul Tarihi: 08.10.2021) 
the temperature increased. This study addresses the efforts of the Turkish army to acquire potable water during the Battles of Canakkale. It also discusses how water was provided to clean soldiers' bodies, clothes, and the environment, as well as the related precautions. The study discusses the impact of these services as a contribution to military logistics in the great triumph of the Turkish army.

Keywords: Battles of Gallipoli, Turkish army, water supply, cleaning

\section{GíRiş}

Savaş zamanlarında ordunun su ihtiyacının karşılanması, erlerin beden ve elbise temizliği askerî lojistiğin bir boyutunu oluşturur. Nitekim harp sahasında ordunun temiz içme suyundan yoksun kalması veya erlerin temizliği hususunda yeterli önlemlerin alınamaması durumunda ordu, kısa sürede büyük bir felaketle karşı karşıya kalabilir.

Çanakkale Cephesi'nde Türkler, ordunun su ihtiyacını karşılayabilmek için önceden herhangi bir tedbire başvurmamıştı. Anlaşılan ordunun su ihtiyacı, muharebe sahasındaki mevcut kaynaklardan istifade edilerek karşılanacaktı. Ancak Gelibolu yarımadası temiz içme suyu kaynakları bakımından, büyük bir ordunun ihtiyacını karşılayacak durumda değildi. Havaların ısınmaya başlamasıyla da yarımadadaki su kaynaklarının büyük bir kısmı kurumaya yüz tutacağı hesaba katıldığından en akılcı yol, deniz suyundan istifade etmekti. Denizden harp sahasına ulaştırılacak bir isale hattı ile ordunun özellikle kullanım suyu sorunu kolayca halledilebilirdi. Ancak ordunun elinde deniz suyunu arıtma cihazları bulunmadığından bu hususta herhangi bir tedbir alınmadı. Dolayısıyla ordunun su ihtiyacı, harp sahasındaki mevcut kaynaklarından karşılanmaya çalışıldı.

\section{ORDUNUN İÇME SUYU İHTIYACININ KARŞILANMASI}

Çanakkale Muharebeleri esnasında askerler, bellerine bağlamadıkları mataralar ile içme sularını daima yanlarında taşımışlardır. Zira harp sahasına intikal eden her eratın üzerinde cephane, kaput, yedek ekmek çantasının yanında 300 gramlık alüminyum matarasının su ile dolu olacak şekilde üzerinde bulundurulması ana tedbirlerden sayılırdı. ${ }^{1}$

Ordunun içme suyu sorunu cephe hattına yapılan intikallerden esnasında başlardı. Nitekim gerek denizyoluyla cephe gerisindeki iskelelere gerekse demiryolu vasitasıyla Uzunköprü İstasyonu'na ulaştırılan birlikler birkaç günlük yürüyüşten sonra ancak cephe hattına ulaşabilirdi. Özellikle muharebelerin başından itibaren denizyoluyla yapılan intikallerin durdurulmasıyla cepheye yapılan intikaller Uzunköprü İstasyonu üzerinde yapılmaya başlandı. Trenle bu istasyona ulaştırılan birlikler buradan yaklaşık bir haftalık bir yürüyüşten sonra cephe hattına ulaşıla biliniyordu. Bu yürüyüşler esnasında birliklerin su ihtiyacının karşılanabilmesi için Menzil noktalarında su fiçıları hazır bulundurulmuşsa da bu tedbirler yetersiz kalmış ve bu intikaller esnasında erler içme suyu hususunda büyük zahmetler çekmiştir.

Cepheye yapılan intikaller esnasında askerlerin su ihtiyacı yürüyüş güzergâhı üzerinde yer alan dere, çeşme, kaynak ve kuyulardan karşılanmaya çalışılırdı. ${ }^{2}$ Ancak

\footnotetext{
${ }^{1}$ Ataksor 2008, s. 159; Özbay 1976, c. II, s. 333.

${ }^{2}$ Bayırı 2015, s. 53-57; İbrahim Naci 2018, s. 69; Özbay 1976, c. II, s. 333.
} 
özellikle Uzunköprü- Gelibolu yol güzergâhında yeterli su kaynağı bulunmadığından bu iki nokta arasında yapılan yürüyüşlerde askerler, su hususunda büyük sıkıntı yaşardı. İbrahim Naci, bu yol güzergâhı üzerinde askerin su hususunda çektiği zahmeti hatıratında şöyle aktarmaktadır: "Asker ise susuzluktan pek zahmet çekiyordu. Adeta disiplin bozulmuştu. Nerede çeşme, dere görse hemen hücum yaplyorlar, sonra bin zahmetle çekebiliyorduk."

Fotoğraf 1. Tam Teçhizatlı Osmanlı Askeri

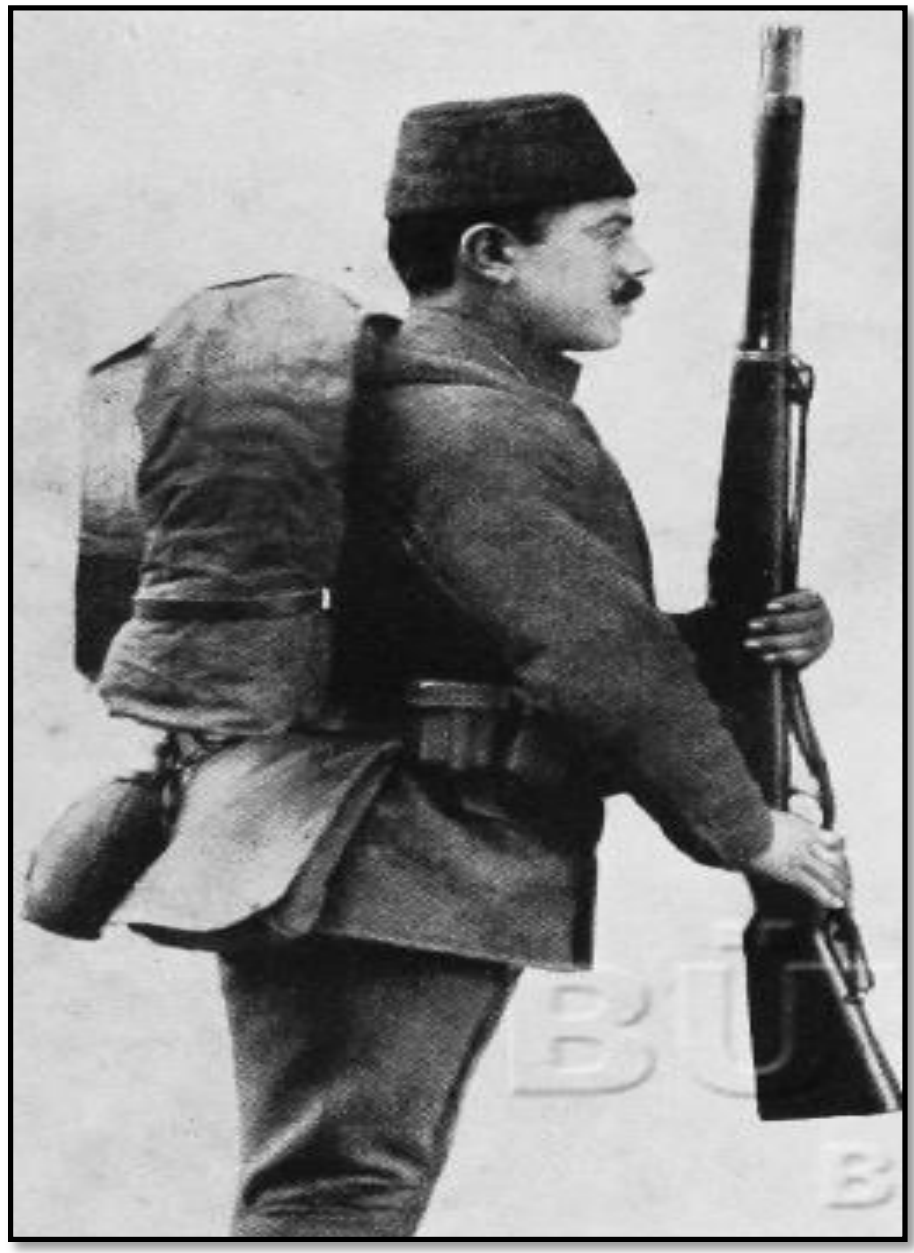

(Kaynak: Piyade Teçhizatı 1327, s. 4-6)

Fotoğraf 2. Arif Bey Çeşmesi’nde Su Iç̧en Osmanlı Neferi

3 İbrahim Naci 2018, s. 63. 


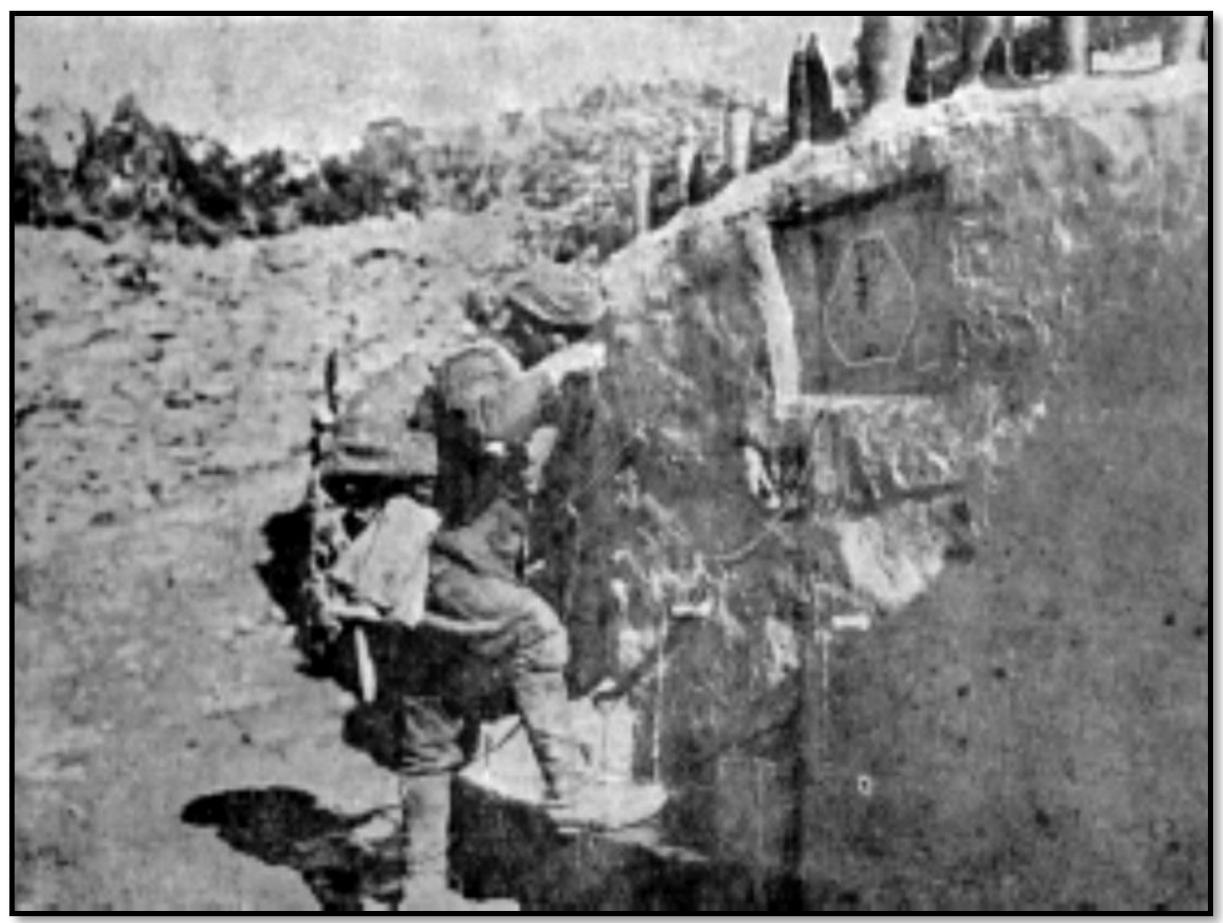

(Kaynak: Harb Mecmûası, Y1l 1, Sayı. 5, Şubat 1331, s. 71)

Gelibolu'dan itibaren cepheye yapılan yürüyüşlerde ise yol güzergâhı üzerinde birbirine yakın irili ufaklı birçok yerleşim yerleri mevcut olduğundan intikalleri esnasında askerin su ihtiyacını genellikle bu bölge halkı tarafından daha önceden inşa edilmiş pınar, çeşme ve kuyulardan karşılanırdı. Bu hususla ilgili olarak İbrahim Naci hatıratında şu ifadelere yer vermektedir: "Orada memnuniyet verici olan nokta ise Gelibolu'dan beri yollarda çeşmelerin pek bol olmastydl. ${ }^{4}$ "

Büyük kuvvetlerin bir araya geldiği cephe hattında ise erlerin su ihtiyacı çok daha büyük bir soruna dönüşür. Zira çatışmalar esnasında büyük güç ve çaba sarf eden askerlerin suya olan ihtiyacı had safhaya ulaşır. ${ }^{5}$ Cemil Conk Paşa bir taarruz anında emrindeki birliğin suya olan iştiyakını ve birliğin su ihtiyacını karşılayabilmek için aldığg tedbiri hatıratında şu şekilde aktarmaktadır:

"Taarruza başladıktan sonra, bir aralık, benden cephane ve takviye kitaları isteneceğini umarken, hiç beklemediğim bir istekle karşılaşmıştım: su su. Illeri hatlarda bulunan askerlerimin yürekleri o kadar yanmış olacak ki su hasretinin ardı arkası kesilmiyordu. Hâlbuki ben, bunu hiç düşünmemiştim. Ne yapacağımı bir anda tasarladım.

\footnotetext{
${ }^{4}$ İbrahim Naci 2018, s. 69

${ }^{5}$ Abdullah Fevzi 2011, s. 238, 251; Sunata 2008, s. 153.
} 


\section{Çanakkale Cephesi’nde Su Temini ve Temizlik Hizmetleri}

Civarımızda bir çeşme vardı. Amele erlere, hemen cephanelerini boşaltmalarını, sandıklara çeşmeden su doldurmalarını emrettim. Bir yandan da cephane sandıklarının içlerinde bulunan çinkodan şeker külahı şeklinde maşrapalar yaptırttım. Su doldurulan her cephane sandiğının içine, bu şeker külahı şeklindeki maşrapalardan birkaç tane arttırdım ve hepsini dakika geçirtmeden ileri hatlara yollattım. ${ }^{6}$,

Muharebe sahasındaki birliklerin su ihtiyacı en yakın pınar, çeşme, kuyu ve derelerden karşılanırdı. ${ }^{7}$ Çatışmaların ara verilmeden günlerce devam ettiği dönemlerde muharip birliklerin su ihtiyacını karşılamak çok daha meşakkatliydi. Bu dönemlerde birliklerin su ihtiyacı saka neferleri tarafından ulaştırılırdı. Saka neferleri, emrine verilen yük hayvanlarının sırtlarında bulunan su fiçılarını ${ }^{8}$ en yakın su kaynağından doldurarak suyu muharebe sahasındaki askerlere ulaştırırdı. ${ }^{9}$

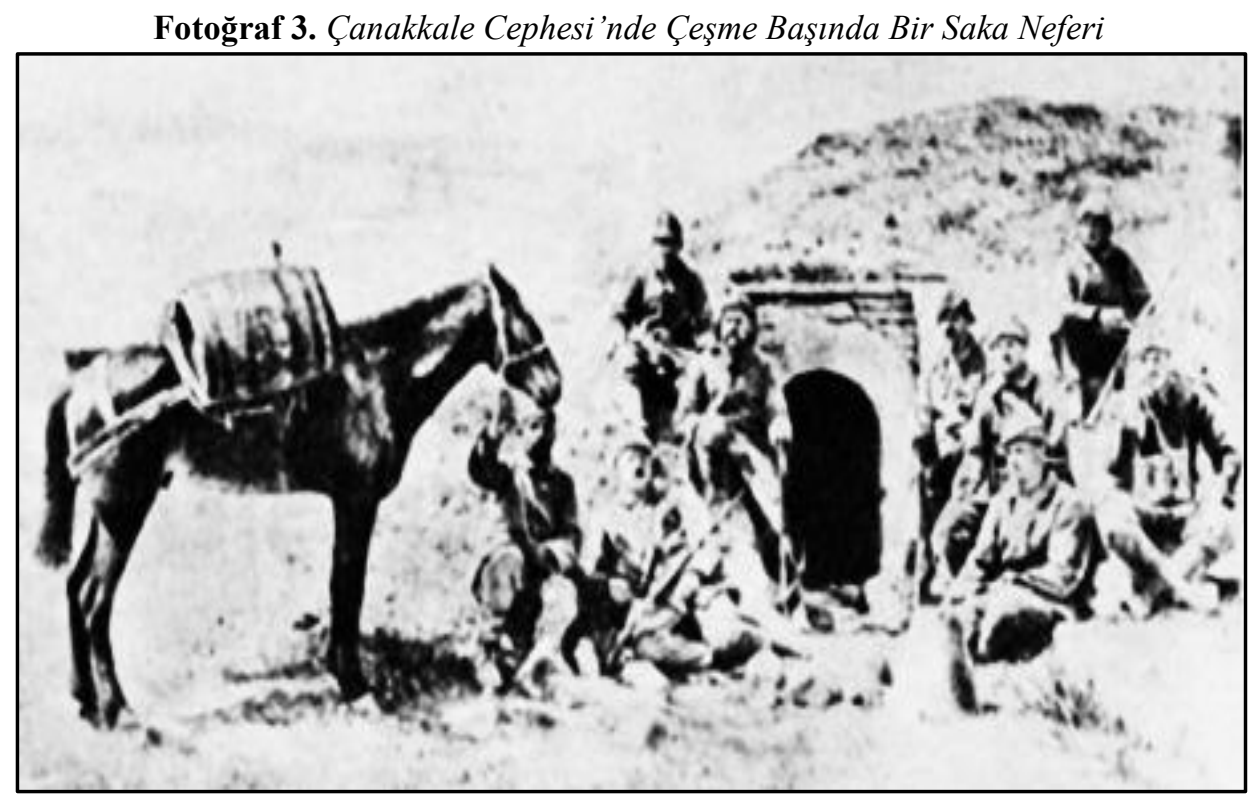

(Kaynak: 6 Numaralı Harb-i Ummumi Panoraması)

Çatışmaların olanca şiddetiyle devam ettiği dönemlerde bu ilkel yolla, büyük bir ordunun su ihtiyacının eksizsiz karşılanamazdı. Dolayısıyla muharebeler esnasında susuz kalan askerler, harbi bırakıp susuzluğunu gidermek için çeşme başlarına üşürürlerdi. İ. Hakkı Sunata çatışmalar esnasında harbi bırakıp çeşme başına üşüşen askerlerin

${ }^{6}$ Conk 2002, s. 132-133.

${ }^{7}$ Sunata 2008, s. 155; İbrahim Naci 2018, s. 55.

${ }^{8}$ Harp esnasında su fiçısı temininde sıkıntı yaşandığından su fiçısı yerine zaman zaman tenekeler veya cephane sandıkları kullanılmıştır. Kannengieseser 2009, s. 146.

${ }^{9}$ Münim Mustafa 2002, s. 96-97; Esat Paşa 2004, s. 196-197; Altay 2002, s. 23. 
vaziyetini hatıratında şöyle aktarmaktadır:

"Bu arada makinelinin ateşi kesilmişti. Ben de yanımdaki askerlerle ilerledim. Daha aşağıda mitralyözün bulunduğu binaların (ki burasının Sülecik Çiftliği’nin binası olduğunu sonradan ögrendim.) sol gerisinde çeşmemsi ve çukurca bir yere askerin hücum ettiğini gördüm. Evvela burada düşmanının var olduğunu zannetmiştim. Sonradan anladım ki burası çeşme imiş. Susuzluktan yanan askerin hepsi, harbi unutarak çeşme başına üşüşmüşler. ${ }^{10 "}$

Havaların ısınmaya başladığı yaz aylarında yalnızca cephe hattındaki ordunun değil aynı zamanda cephe gerisindeki birliklerin de su ihtiyacını karşılamakta sıkıntılar yaşanırdı. Yarımadadaki su kaynakları genellikle kar ve yağmur sularıyla beslendiğinden sıcakların artmaya başlamasıyla bölgedeki su kaynaklarının büyük bir kısmı kururdu. ${ }^{11}$ Askerin su ihtiyacının her zamankinden fazla olduğu bu aylarda temiz su kaynaklarının büyük kısmı çekildiğinden ordu, su temininde sıkıntı yaşardı.

Yaz aylarında Gelibolu yarımadasındaki temiz su kaynakları daha da azaldığından ordunun temiz su ihtiyacını karşılayabilmek için ordu istihkâm taburlarında bulunan kuyucu takımlarıyla dere yataklarında artezyen kuyuları açtırılırdı. ${ }^{12}$ Yurtdışında temin edilen kuyu burgu aletleri vasıtasıyla 10-15 metre derinliğinde artezyen kuyuları açılır ve bu kuyuların başına tulumba takılarak kullanıma hazır hale getirilirdi. ${ }^{13}$

Fotoğraf 4. Birinci Dünya Savaşı Yıllarında Bir Artezyen Kuyusunun Açılışı

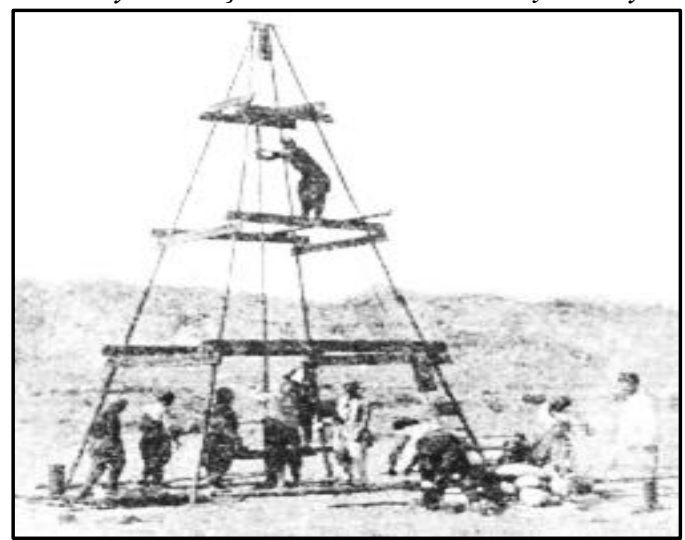

(Kaynak: Harb Mecmûası, Y1l 1, Say1 3, s. 38)

Muharebe sahasındaki su kaynakları yetersiz olmakla birlikte bu suların temiz ve

${ }^{10}$ Sunata 2008, s. 146.

11 Bölge, en fazla yağışı kış mevsiminde, en az yağışı ise yaz aylarında alır. Bu yönüyle bölge Akdeniz yağış rejimi özelliğini gösterir. Yaşar 2001, s. 177.

12 Bayrı 2015, s. 60; Genişol 2014, s. 18-19; Borlat 2020, s. 284-285

13 Osmanlı Devleti harp döneminde artezyen kuyularının açılabilmesi için gerekli burgu aleti ve diğer yardımcı alet ve edevatı gümrük vergisinden muaf tutuldu. Artezyen kuyuları açmak için yurtdışından özellikle de Almanya'dan getirtilen bu kuyu burgu aletlerinden, Çanakkale Cephesi'ne de gönderildi. BOA, ŞD., 1249/39; BOA, BEO, 4296/322159; Esenkaya 2014, s. 75. 


\section{Çanakkale Cephesi'nde Su Temini ve Temizlik Hizmetleri}

içilebilir olması erlerin salgın hastalıklardan korunması açısından son derece önemlidir. $\mathrm{Bu}$ bakımdan Sahra Sihhiye Müfettişi Süleyman Numan Paşa emriyle muharebe alanlarındaki sular muayeneden geçirilmeye başland $1 .{ }^{14}$ Suyu muayene edilen çeşmelerin üzerine ise renkli tebeşirle "suyu içilir veya suyu içilmez" ibaresi yazılırdı. ${ }^{15}$ Cephedeki kuyuları temizlemek veya gerektiğinde yenilerini açmakla görevlendirilen Teğmen Şerif Bey sayesinde kirli su kuyuları permanganatla ${ }^{16}$ temizlendiği gibi üstü açık olan kuyulara da tulumbalar taktırıldı. Bu kuyuların yeniden kirletilmemesi için de kuyuların etrafı tel örgülerle muhafaza altına alındı. ${ }^{17}$ Suyu içilemez durumda olan kuyular gaz atılarak tahrip edilir veya su kaynağının sağlıksız olduğunun anlaşılabilmesi için kaynağın başına sarı flama asılırd1. ${ }^{18}$

Ordunun su ihtiyacı elbette yalnızca içme suyundan ibaret değildi. Cephe gerisinde erlerin kişisel ve çevre temizliği başta olmak üzere mutfak ve diğer hizmetler için de suya ihtiyaç vardı. Orduların geri hizmetlerinin sorunsuz yürüyebilmesi için suyu kolayca temin edilmek için ordugâh merkezleri, sahra mutfakları, sağlık ve temizlik merkezleri genellikle dere yataklarında kurulmuştur. ${ }^{19}$ Ancak dere yataklarındaki sular üstü açık olduğundan bu sular, sağlık açısından büyük risk taşır. Özellikle yaz aylarında dere suları ya tamamen kurur veya iyice azalarak sızıntı şekline küçük oyuklarda biriken durgun sulara dönüşürdü. ${ }^{20} \mathrm{Bu}$ nedenle bir yandan dere yataklarının kirletmesi için tedbirler alınır bir yandan da dere yataklarında muvakkat çeşmeler veya artezyen kuyuları açtırılırdı. ${ }^{21}$ Kirli suların temiz su kaynaklarına ulaşması için de drenaj kuyuları açtırıldı. Tetkik edilmemiş veya kirli olduğundan şüphelenilen sular ise kaynatılarak kullanılmaya başland1. ${ }^{22}$

Tüm bu önlemlere rağmen askerler arasında tifo, kolera, ishal ve dizanteri gibi kirli ve pis sulardan bulaşan hastalıklar görüldü. Temiz içme suyu bulamayan askerler, su ihtiyacını dere yataklarındaki durgun ve pis sulardan karşılamak zorunda kaldı. İnsan ve hayvan dışkılarının dere sularına karşımasını önlemek mümkün olmadığından orduda kirli sularla bulaşan sıtma, tifo, kolera, ishal ve dizanteri gibi salgın hastalıkların önüne geçilemedi. ${ }^{23}$ Aşı ve sıhhi tedbirler sayesinde bu salgın hastalıklar muharebeleri etkileyecek düzeye erişmeden bertaraf edilebildi. ${ }^{24}$

Netice itibariyle Çanakkale muharebelerinin yaşandığı coğrafya su kaynakları

\footnotetext{
${ }^{14}$ Noyan 1956, s. $42-43$.

${ }^{15}$ Noyan 1956, s. 37.

${ }^{16}$ Noyan 1956, s. 14.

${ }^{17}$ Esenkaya ve Marttin 2009, s. 262.

${ }^{18}$ Arikan 2007, s. 33; Noyan 1956, s. 14, 29.

${ }^{19}$ Bayır1 2015, s. 60; Özgen 2011, s. 22.

${ }^{20}$ Conk 2002, s. 213; Abdullah Fevzi 2011, s. 232-233; Safiyyüddin Efendi 2019, s. 53; Kannengiesser 2009, s. 170.

${ }^{21}$ Noyan 1956, s. 48.

22 Özellikle kolera vakalarının görüldüğü bölgelerde suların kaynatılarak içilmesine özen gösterilirdi. BOA, BEO, 4113/308434; Özbay 1976, c. I, s. 333.

${ }^{23}$ Çalık ve Tepekaya 2006, s. 218.

${ }^{24}$ Noyan 1956, s. 48; Başustaoğlu 2016, s. 269; Özbay 1976, c. I, s. 312-313; Sınmaz Sönmez 2016, s. 181; Çalık ve Tepekaya 2006, s. 214-215.
} 


\section{Yavuz Selim ÇELOĞLU}

bakımdan zengin sayılmazdı. Bu bakımdan ordunun su ihtiyacını karşılamakta zaman zaman büyük zorluklar yaşand $1 .{ }^{25}$ Buna rağmen Türk tarafının düşmana karşı en büyük belki de yegâne avantajı temiz su kaynaklarına sahip olmasıydı. ${ }^{26}$ Bu durum özellikle kara savaşlarında Türklere büyük avantaj sağlamıştır. Alman komutan Hans Kannengiesser, Türklerin kara savaşlarında gösterdiği başarıya etki eden dört faktörden birinin Türklerin suya kolayca ulaşması olarak zikreder. ${ }^{27}$ Türklerin bu avantajının farkında olan İtilaf kuvvetleri, zaman zaman Türk ordusunun su kaynakları ile olan bağlantısını kesme için girişimlerde bulundu. Nitekim Ian Hamilton harp esnasında Türklerin su ikmal kuyuların bulunduğu bölgeyi ele geçirmek için yaptığı taarruz hakkında hatıratında şunları aktarmaktadır: "Kesinlikle h.12 bölgesini ele geçirmeliyiz. Çünkü tutsaklar Türk birliklerinin su ikmallerini yaptıkları kuyuların bu bölgede ve kendi kanatlarında olduğunu açıkladılar. ${ }^{28 "}$

\section{CEPHEDE TEMIZLIK FAALIYETLERİ}

Harp sahasında büyük bir insan kitlesinin bir araya getirilmesi ve ağır savaş koşulları askerler arasında hastalıkların yayılmasına zemin hazırlar. Orduyu hastalıklardan korumanın en basit ve etkili yolu ise askerin kişisel temizliği ile barınma ve çevre koşullarının temizliğine azami özen ve itinanın gösterilmesiyle mümkün olur. Bu temizlik hizmetleri için de muharebe sahasına yeterli suyun ulaştırılması gerekir.

\subsection{Askerin Kişisel Temizliği}

Harp sahasındaki bulaşıcı hastalıkların önemli bir kısmı erlerin kişisel temizliklerinin ihmal edilmesinden kaynaklanır. Osmanlı Devleti bu hakikati en son Balkan Harplerinde acı şekilde tecrübe etmişti. ${ }^{29}$ Dolayısıyla Çanakkale Muharebelerinin başlamasıyla birlikte ordu idare heyeti, muhtemel salgınları önleyebilmek amacıyla çeşitli önleyici tedbirlere başvurdu. Birliklerin harp sahasına intikal etmesinden itibaren ordu veya kolordu sertabipleri nezaretinde karantina veya temizlik mahalleri oluşturulmaya başland $1 .{ }^{30}$ Özellikle ülkenin çeşitli yerlerinde hüküm süren hastalıkların harp sahasına ulaşmasını engelleyebilmek amacıyla harp alanına dâhil olan erler önce "Tahaffuzhane" adı verilen merkezlerde üç günlük karantinaya tabi tutulurlardı. Bu süre zarfında erler, genel sağlık kontrolünden geçirilirdi. Böylece hastalıklı erler ayıklanarak tedavi altına alınır veya aşıları eksik olan erlerin aşıları tamamlanırdı. Ayrıca özellikle bitlenen erlere banyo yaptırılır ve elbiseleri etüvden geçirilerek temizlik hususundaki eksiklikleri giderilirdi. $^{31}$

Salgın hastalıkların ordu içindeki yayılımını engellemek için erlerin belli

\footnotetext{
${ }^{25}$ Abdullah Fevzi 2011, s. 238; Özdemir 2010, s. 215.

${ }^{26}$ Kannengiesser Pasha 2015, s. 224-225; Schweder 2012, s. 153, 155, 161; Zembrzuska 2019, s. 54.

${ }^{27}$ Kannengiesser 2009, s. 269.

${ }^{28}$ Hamilton 2006, s. 230.

29 Tevfik Salim 1935, s. 493; Sihhiye Mecmuas1 1333, s. 11-12, s. 1068.

${ }^{30}$ ATASE Arșivi, BDH, Kls. 1126, Dos. 11, Fih. 7/1.

${ }^{31}$ Esenkaya ve Martin 2009, s. 268-269.
} 


\section{Çanakkale Cephesi’nde Su Temini ve Temizlik Hizmetleri}

aralıklarla yıkanması ve elbiselerinin temizlenmesi gerekirdi. Bunun için ise cephe hattındaki erlerin, zaman zaman geriye alınması gerekir. Ancak özellikle kara muharebelerinin başlamasıyla birlikte cephede yoğun çatışma devresine girildiğinden askerin geriye alınarak temizlenmesine ne zaman ne de imkân vardı. Askerler uzun süre yıkanamadığından orduda bitlenme vakaları yaygın olarak görülmeye başlandı. ${ }^{32}$ Başlangıçta askerlerin nazarında bitlenme büyük bir sorun teşkil ederken askerler de zamanla bu durumu kanıksanmıştır. Nitekim cephede bitlenen askerin bu duruma gösterdiği tepkiyi Mümin Mustafa, hatıratında şu ifadelerle aktarmaktadır:

"Ylkanmaya ne vakit ne de imkân vardl. Bu suretle üzerimizde tek tük görünen hayvancıkları başlangıçta def etmek için hayli uğraşmıştık. Fakat sonraları bunlara da alışmaya başladık. Yakamızın etrafina sıra ile dizildiğini gördüğümüz vakit onları birer fiske ile yere düşürmeyi kâfi görürdük. ${ }^{33}$ "

Erler arasında bitlenme vakalarının artmasıyla ordu idaresinde bunun bir salgına dönüşeceği endişesini yarattığında temizlik hususunda daha sıkı önlemler alınmaya başlandı. Öncelikle bulaşıcı hastalıkların ortaya çıkmasını engellemek amacıyla her fert, hastalıkla mücadele etmekle yükümlü kılındı. Bununla birlikte ordu harekât alanın gerilerinde "Tathir Merkezleri" (temizleme istasyonları) ile "Muayene Merkezleri" oluşturuldu. ${ }^{34}$ Başlangıçta er ikmalinin yoğun olarak yapıldığı Uzunköprü-Gelibolu hattı üzerinde yer alan Keşan'da 3 seyyar etüv merkezi ile bir menzil temizleme istasyonu açıld1. ${ }^{35}$ Zamanla Lâpseki, Hayrabolu, Muradlı, Lüleburgaz, Seyidler, Malkara, Uzunköprü ve Biga gibi er ikmal yolları üzerinde de temizleme istasyonları açıldı. Bu merkezlerde kurulan portatif çadırlar ve barakalarda bir yandan askerler yıkanırken bir yandan da elbiseleri etüvden geçirilerek bitlerden arındırılırdı. ${ }^{36} \mathrm{Bu}$ merkezlerdeki temizlik hizmetleri ise zabit ve hizmet erlerinden oluşan "tathir müfrezeleri" tarafından yürütülürdü. ${ }^{37}$. Banyo esnasında erlerin iç çamaşırı büyük oranda yenileri ile değiştirilirken pantolon, ceket ve kaban gibi dış giyim elbiseleri de etüvden geçirilerek bitten arındırılırdı. Muharebeler esnasında askerin elbiselerinin bitten arındırılması için en fazla başvurulan yol elbiselerin etüvden geçirilmesiydi. ${ }^{38}$ Etüv cihazı sayesinde elbiseler sıkıştırılmış buhara maruz bırakılarak bitten arındırılırdı. ${ }^{39}$

Etüv cihazları seyyar ve sabit olmak üzere iki şekli tasarlanmıştı. $774 \mathrm{~kg}$.

32 Arıkan 2007, s. 52; Münim Mustafa 2002, s. 58, 96, 125.

${ }^{33}$ Münim Mustafa 2002, s. 58

${ }^{34}$ Muzaffer 1339, s. 66-67.

${ }^{35}$ Gözcü 1937, s. 89.

${ }^{36}$ ATASE Arşivi, BDH, Kls. 3528, Dos. 25, Fih. 2; ATASE Arşivi, BDH, Kls. 3527, Dos. 21, Fih. 29, 29-1; ATASE Arşivi, BDH, Kls. 1150, Dos. 107, Fih. 6-20; ATASE Arşivi, BDH, Kls. 3535, Dos. 56, Fih.7; BDH, Kls. 1181, Dos. 226, Fih. 44-6; Hasan Cevdet Bey 2015, s. 34; Münim Mustafa 2002, s. 125; Conk 2002, s. 141.

${ }^{37}$ Lapseki'deki Tathir merkezindeki tathir müfrezesi 1 zabit ve 28 erden oluşurken Hayrabolu, Muradlı ve Malkara tathir merkezindeki tathir müfrezeleri 1'er zabit ve 10'ar erden oluşuyordu. ATASE Arşivi; BDH, Kls. 1157, Dos. 133, Fih. 1-53. ATASE Arşivi, BDH, Kls. 1181, Dos. 226, Fih. 44-5, 44-6, 44-7, 44-9.

${ }^{38}$ Hasan Cevdet Bey 2015, s. 54; Conk 2002, s. 141.

${ }^{39}$ Esenkaya ve Martin 2009, s. 267. 


\section{Yavuz Selim ÇELOĞLU}

ağırlığında olan seyyar etüvler, bir veya iki yük hayvanına koşulacak şekilde tasarlandığından istenilen mevkilere kolayca taşınırdı. Her iki etüv cihazının çalışma şekli ayniydı. Odun veya kömürle isitılan su, bir boru vasitasiyla buhar halinde elbiselerin bulunduğu kazana aktarılırdı. Buhar kazanında bulunan eşyalar, 20-30 dakika sıkıştırılmış buhara maruz bırakılır ve böylece elbiseler bit ve haşerelerden arındırılırdı. Seyyar etüvle her bir temizleme işleminde 8 kişinin elbisesi temizlenebilirdi ${ }^{40}$

\section{Resim 1. Seyyar Etüv Cihazı}

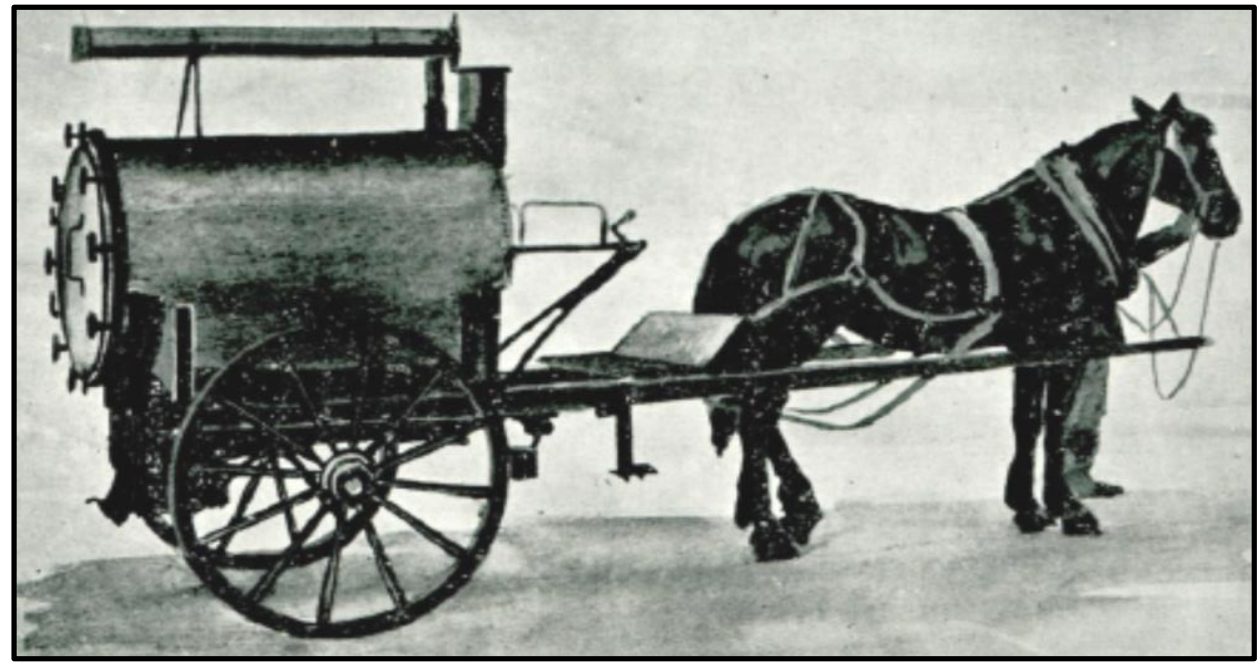

(Kaynak: Sihhiye Mecmuası 1333, s. 1066-1067.)

Sabit etüv cihazları seyyar etüvlere nispeten daha büyük şsekilde tasarlandığından daha çok karantina ve temizleme istasyonları ile cephe gerisinde inşa edilmiş menzil hastanelerinde kullanılırdı.

Osmanlı Devleti harp süresince etüv cihazlarını büyük oranda müttefiki Almanya ve Avusturya'dan temin etmeye çalışıı̧tır. Ancak harbin başlamasıyla Avrupa yolu kapandığından etüv cihazı temininde büyük sıkıntı yaşandı. Buna rağmen tüccarlar vasıtasıyla Almanya'dan satın alınan sınırlı sayıdaki etüv makineleri Selanik üzerinden ülkeye sokuldu. ${ }^{41}$

Resim 2: Sabit Etüv Cihazı

${ }^{40}$ Sihhiye Mecmuasi 1331, s. 995.

${ }^{41}$ BOA, HR.H., 37/10; BOA, HR.SFR., 879/81; Sthhiye Mecmuast, S. 11-12, s. 1065-1066. 


\section{Çanakkale Cephesi’nde Su Temini ve Temizlik Hizmetleri}

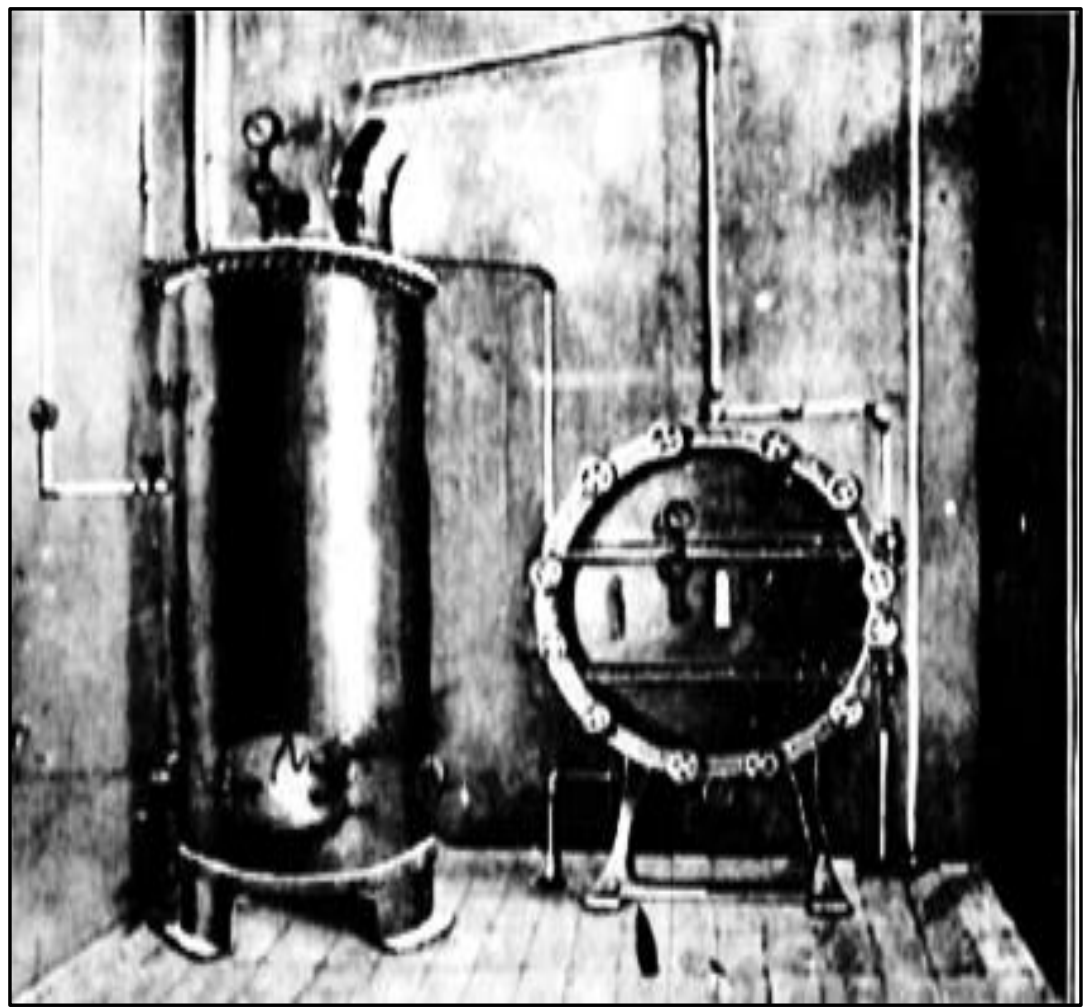

(Kaynak: S1hhiye Mecmuas1 1333, s. 1066-1067)

Muharebeler esnasında yeterli etüv cihazı bulunmadığından erlerin elbise temizliği için firınlama ve buğu sandıkları gibi dönem şartlarının zorunlu kıldığı uydurma vasıtalara başvuruldu. ${ }^{42}$ Ahmet Fikri Bey tarafından tasarlanan bu "buğu sandıklarl" etüvlerde olduğu gibi elbise ve eşyalar yüksek buhara maruz bırakılarak temizlenirdi. Buğu sandıkları, bir kazan ve sandık olmak üzere iki bölümden oluşurdu. Sandık bölümünün uzunluğu 2 metre, yarıçapı ve yüksekliği ise 1'er metre olarak inşa edilirdi. Sandık bölümünün yapımı için kalınlığ $12 \mathrm{~cm}$.'yi bulan tahtalar ile bir miktar çivi yeterliydi. Buna kazanın eklenmesiyle de buğu sandığının yapımı tamamlanıyordu. Dolayısıyla buğu sandıkları, etüvlere nazaran yapımı oldukça kolay ve çok daha ucuza mal olduğundan küçük bir atölyede dahi çok sayıda buğu sandığı üretmek mümkündü. Buğu sandıkları da tıpkı etüvlerde olduğu gibi basınçlı buharla dezenfekte işlemi yaptığından elbiselerin zarar görmeden etkili bir şekilde temizleniyordu. Buğu sandıklarının kullanımı da oldukça basitti. Kazanın yakılmasından yaklaşık yarım saat sonra eşyalar temizlenmiş olurdu. ${ }^{43}$ Muharebeler esnasında yeterli sayıda etüv cihazı

42 Tevfik Salim 1935, s. 493; Özbay 1976, c. I, s. 238.

${ }^{43}$ Sihhiye Mecmuas1 1333, s. 1079-1081; Özbay 1976, c. I, s. 313-314. 


\section{Yavuz Selim ÇELOĞLU}

temin edilemediğinden buğu sandıkları yaygın olarak kullanıldı. Etüvlere nazaran oldukça ucuza mal edilebilen buğu sandıklarının yapımı, tamir ve onarımı da oldukça kolay olduğundan kısa sürede üretilerek cephede etkin olarak kullanıldı. ${ }^{44}$ Dolayısıyla muharebeler esnasında buğu sandıklarının etüvlerden ziyade iş gördüğünü söylemek mümkündür. ${ }^{45}$

Resim 3: Dr. Ahmet Fikri'nin Buğu Sandı̆

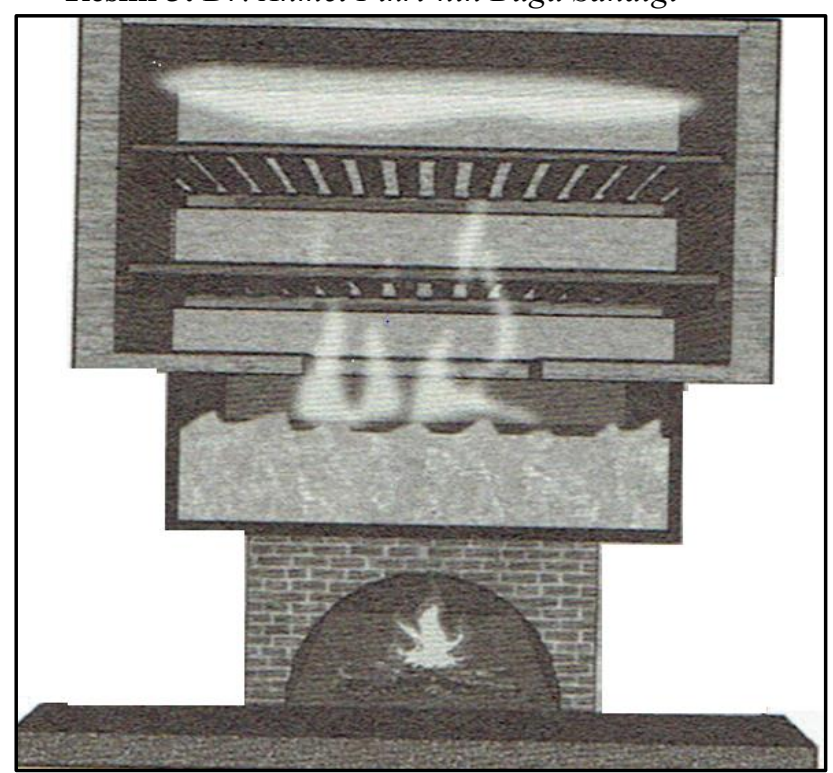

(Kaynak: Başustaoğlu 2016, s. 274)

Elbiselerin ve eşyaların bitten arındırmanın diğer bir yolu ise elbiselerin firınlanmasıydı. ${ }^{46}$ Etüv ve buğu sandıklarının bulunamadığı durumlarda elbiseler, sahra veya ekmek firınlarında belli bir süre bekletilerek bit ve haşerelerden arındırılırdı. ${ }^{47}$

Resim 4: Sahra Fırınlarının İ̧̧ ve Dış Görünüşü

\footnotetext{
${ }^{44}$ Başustaoğlu 2016, s. 273-274.

45 Özbay 1976, c. I, s. 314; Noyan 1956, 40-41.

${ }^{46}$ Çanakkale Cephesi, s. 235.

${ }^{47}$ Fırınla yapılan dezenfeksiyon işlemini Tevfik Sağlam şu şekilde tarif etmektedir. "Fırın içinde ateş yakılır, 1sı derecesini tayin için elde termometre bulunmadığından içine beyaz bir kağıt koyulur, kağıt tam kavrulmaz ama sararırsa uygun 1sı derecesinde olduğu anlaşılır. Içinden ateş çekilir, fırının zeminine yaş bir çuval serildikten sonra, üzerine su püskürtülmüş elbiseler gevşek olarak yayılır, firın kapısı kapanır ve 10-15 dakikada bitler tamamen ölürdü. Bu elbiseler çıkarıldıktan sonra, firını tekrar 1sıtmaya gerek kalmadan, ikinci kez koyulan elbiseler 20-25 dakika, üçüncüsünce yarım saat tutulurdu. Fırını bir defa 1sıtmakla üç kez dezenfeksiyon yapılabilirdi.” Başustaoğlu 2016, s. 272.
} 


\section{Çanakkale Cephesi’nde Su Temini ve Temizlik Hizmetleri}

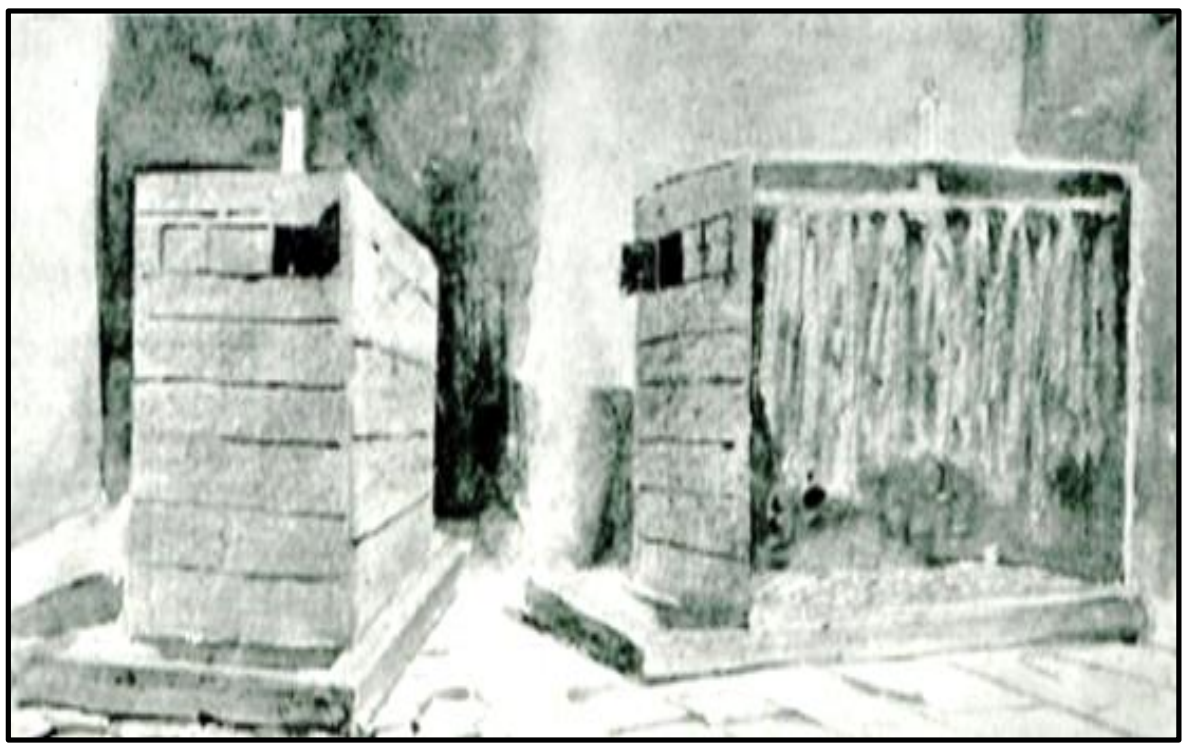

(Kaynak: Sihhiye Mecmuası 1333, s. 1089)

Ancak kuru sıcak hava ile yapılan bu temizleme usulünde eşyaların yanması ve bozulma ihtimali oldukça yüksekti. Bu bakımdan etüv ve buğu sandıklarının bulunmadığı durumlarda firınlama yönteminden faydalanılırdı. ${ }^{48}$ Tüm bunların yanında etüv, buğu sandıkları ve firınlama imkânının bulunmadığı durumlarda elbise ve eşyaları bitten arındırabilmek için eşyalar okzalit asit (hamz-1 humaz ${ }^{49}$ ) ile yıkanır veya kükürtle dezenfekte edilirdi. ${ }^{50}$

Erlerin temizliği hususunda yaşanan bir diğer sorun da sabun gibi temizlik ürünlerinin yetersiz olmasıdır. Temizliğin vazgeçilmek ürünü sabun, büyük oranda zeytinyağından üretilirdi. Ancak harbin başlamasıyla hemen her alanda olduğu gibi zeytinyağı temininde de büyük sıkıntı yaşand1. Ordunun sabun ihtiyacını sabun üretiminin yoğun olarak yapıldığı Aydın, Balıkesir, Hüdavendigar, Karesi ve Kala-i Sultaniye vilayetleri başta olmak üzere ülke genelindeki sabun imalathanelerinde bulunan sabunların \%25'ine el konularak ordunun ihtiyacı karşılanmaya çalışıldı. Ancak ordunun ihtiyacının yalnızca bu usulle karşılamak mümkün olmadığından mübayaa (satın alma)

${ }^{48}$ Asker giysilerinin en iyi temizlenme şekli kuşkusuz elbiselerin su ile yıkanmasıdır. Ancak harp esnasına giysilerin kısa sürede yıkanıp kurutulması pek mümkün olmadığından elbiselerin buharla temizlenmesi yani etüvden geçirilmesi en iyi çözümdü. Ancak bu etüvlerin bulunmadığ1 durumlarda ise elbiseler fırınlanma gibi ilkel yolla temizlenmeye çalışılırdı. Abdülkadir Bey 1332, s. 479; Çanakkale Acı İlaç, s. 50; Conk 2002, s. 141.

${ }^{49}$ Temizlenme maddesi olarak kullanılan asit.

50 Eşyalar kapalı bir alanda 24 saat kükürt buharına maruz bırakılarak bit ve haşerelerden arındırılırdı. ATASE Arşivi, BDH, Kls. 1126, Dos. 11, Fih. 7-1; Sthhiye Mecmuası 1333, s. 10791081 . 
yoluna gidildi. Ayrıca Rumlardan metruk kalan yemeye elverişsiz zeytinlere de el konularak ordu için sabun imal edildi. ${ }^{51}$ Ancak ekmek gibi en temel ihtiyacın temininde dahi büyük müşkülatın yaşandığı bir dönemde birçok üründe olduğu gibi sabun temininde de büyük sıkıntı yaşand1. ${ }^{52}$

Muharebeler esnasında gerek erlerin beden gerekse elbise ve yaşam alanlarının temizliği oldukça sınırlı kaldı. Bu nedenle erler arasında bitlenme vakaları yaygın olarak görülüyordu. Bitler ise tifüs veya dönemin tabiriyle lekelihumma ${ }^{53}$ ve hummai racia ${ }^{54}$ hastalığının temel nedenlerindendi. Muharebeler esansında temizlik hususunda alınan tedbirler ve aşılama faaliyetleri sayesinde muharebeler esnasında bitlenmeden kaynaklanan tifüs hastalığı bir salgına dönüşmeden bertaraf edilebildi. Nitekim harp süresince 5'inci Orduda yalnızca 149 askerde tifüs vakasına rastlanmış ve bunların 36's1 ise hayatını kaybetmişti. ${ }^{55} \mathrm{Bu}$ rakamlardan da anlaşılacağı üzere Çanakkale Muharebeleri esnasında tifüs hastalığı salgın halini almadan kontrol altına alınabilmiştir. ${ }^{56}$ Bitlerin neden olduğu bir diğer hastalık olan hummai racia hastalığı da bir salgına dönüşme imkânı bulamadan bertaraf edilmiştir. ${ }^{57}$ Ancak muharebelerin sonlarına doğru iaşenin gün geçtikçe bozulması, siperlerde aylarca kalan askerlerin kişisel temizliğinin yapılamaması, verilen emirlere rağmen genel hijyen kurallarına yeterince riayet edilemediğinden askerler arasında salgın ortaya çıkmıştır. ${ }^{58}$

\subsection{Askeri Barınma ve Mıntıka Alanı Temizliği}

Temizlik hizmetlerin bir diğer boyutunu da askerlerin yaşadıkları çevre ve barınma koşulları oluşturur. Büyük kuvvetlerin uzun süre bir arada bulunması erlerin barınma koşullarını ve çevre temizliğini zora sokar. Savaşın ağır koşulları altında derinliği 2-3 metreyi bulan siperlerde veya siper gerisinde portatif çadırlarda veya

${ }^{51}$ BOA, DH.İ.UM.EK., 27/29; BOA BEO, 4451/333783; BOA, MV., 205/91.BOA, DH.İ.UM, 93/1; BOA, DH.İ.UM.EK., 34/2; BOA, DH.İ.UM, 81/1; BOA, DH.İ.UM.EK., 14/80.

${ }^{52}$ BOA, DH.İ.UM., 89/1; Özbay 1976, c. I, s. 312.

${ }^{53}$ Lekeli Humma hastalığı, bitler vasıtasıyla insana bulaşan ve salgın halinde seyreden ateşli bir hastalıktır. Ateşin yükselmesinden ortalama 4 ile 6 gün sonra omuz ve gögüs ve kollarda pembe renkli deri döküntüleri oluşmaya başladığından bu hastalığa halk arasında lekeli humma hastalığı olarak da anılırdı. Özer 2016, s. 219.

${ }^{54}$ Hummai racia hastalığında hastanın ateşi bir yükselip bir alçaldığından bu hastalığa "geri dönen ateş" anlamında dönek ateş adı da verilir. Lekeli hummada olduğu gibi bitler vasıtasıyla bulaşır. Server Kâmil 2016, s. 16.

${ }^{55}$ Esenkaya 2011, s. 32; Sinmaz Sönmez 2016, s. 181; Aysal 2015, s. 23.

56 Oysa aynı dönmede özellikle 3'üncü ve 6'ncı Ordular tifüs salgınından dolayı adeta kırıma uğramıştı. Nitekim 3'üncü Ordu bünyesinde 19.619 tifüs vakasından 7.310'u ölümle sonuçlanmıştı. 6'incı Ordu bünyesinde ise 4.983 tifüs vakası tespit edilmiş ve bunların da 1.305 'i ölümle neticelenmişti. Başustaoğlu 2016, s. 285; Sınmaz Sönmez 2016, s. 181; Özer 2016, s. 251-252.

${ }^{57}$ ATASE Arşivi, BDH, Kls. 1129, Dos. 27, F. 2; Gözcü 1937, s. 89; Erduran 2015, s. 137; Noyan 1940, s. VI; Çanakkale Acı İlaç, s. 50; Çanakkale Harekâtı, s. 546.

58 Özbay 1976, c. I, s. 236. 


\section{Çanakkale Cephesi’nde Su Temini ve Temizlik Hizmetleri}

zeminliklerde temizliğe gereken özeni göstermek oldukça zordur. ${ }^{59}$

Muharebeler esnasında çevre temizliği hususunda yaşanan en büyük sorunlardan biri erlerin barınma yerlerinde yeterince hela inşa edilmemiş olmasıydı. Bazı birliklerin bulunduğu yerlerde yeterli hela bulunmadığından barınma yerlerinin etrafi insan pisliğiyle kirletildiğinden özellikle Asya Grubunun bazı birliklerinde dizanteri şeklinde ishal vakaları görüldü. Bunun üzerine tuvaletlerle ilgili önlemler alınmaya başlandı. Birliklerin bulunduğu mevkilere yeni helalar inşa edildiği gibi siperlerde bulanan erlerin hela ihtiyacı için de siperlerin gerisinde gizli ve örtülü yollarla ulaşılan sahra helaları ve el yıkama yerleri oluşturuldu. ${ }^{60}$ Bir salgın hastalığa mahal vermemek için de helalar taze kireç sütü ve tozu ile dezenfekte edilmeye başlandı. ${ }^{61}$ Böylece erler arasında görülen münferit dizanteri vakaları, bir salgına dönüşmeden bertaraf edilebildi. ${ }^{62}$

Çevreden kaynaklı bir başka tehdit de birliklerin yakınında bulunan bataklıklar ve küçük su birikintileriydi. Bu alanların ıslahı için drenaj kuyularının açtırılması gerekirdi. Sahra Sıhhiye Müfettişi Umumi Vekili sıfatı ile görev yapan Prof. Mayer, öncülüğünde harp sahasındaki atık su birikintileri ve bataklıkların kurutulabilmesi için büyük çaba harcand1 ${ }^{63}$ Çanakkale Muharebe alanı içinde Kumkale'den Pınarbaşı'na kadar olan oldukça büyük bir sazlık ve bataklık alan bulunuyordu. Bu bataklık alan nedeniyle bölgede bulunan birliklerde sıtma hastalığı yaygın olarak görülüyordu. Ancak savaş esnasında bu denli büyük bir bataklığı kurutma girişimde bulunma olanağı bulunmadığından bu bölgedeki birliklerde sıtma vakaları yaygın olarak görülüyordu. Alman Islahat Heyeti Sağlık Müşaviri Dr. Mayer, sıtma hastalığına neden olan sinekleri bölgeden uzaklaştırabilmek için oldukça ilkel sayılabilecek bir yönteme başvurmuştu.

“Bataklık zemin nedeniyle özellikle Kumkale'deki mevzilerde, sitma ile mücadele amacıyla drenaj yapmaya imkân yoktu. Bu yüzden Anadolu Grubu Komutanı'na, Kale Komutanı'na ve özellikle de Amiral von Usedom 'a, karanlık bastığında etraftan, deve, at, öküz, ne bulurlarsa, hayvanların kurutulmuş gübrelerini, küçük kümeler halinde çadırların etrafina paralel şekilde dizerek ateşe vermeyi ve sonra üstünü toprakla örtmeyi teklif ettim. En azından, sivrisineklerin büyük kısmı böylece kaçırllabilirdi. ${ }^{64 "}$

Tüm bu çaba ve gayretlere rağmen harp halinde iken köklü bataklık kurutma girişmek mümkün olmadığından şahsi koruma tedbirleri ve genel hijyen kurallarına riayet edilerek sıtma hastalığıyla mücadele edilmeye çalışıldı. Bu tedbirlere rağmen birliklerde zaman zaman sıtmadan kaynaklanan ölümler yaşandı. ${ }^{65}$

Çanakkale muharebeleri esnasında Türk ordusu siperler başta olmak üzere yaşam alanlarını temiz tutmak konusunda büyük çaba göstermiş ve bunda da nispeten başarılı olunmuştur. Nitekim boşaltılan düşmanın siperlerini gezerken siperlerin durumu

\footnotetext{
${ }^{59}$ Münim Mustafa 2002, s. 54-55, 94, 96, 117, 120, 125; Abdullah Fevzi 2011, s. 238; Özdemir 2010, s. 215.

${ }^{60}$ Genişol 2014, s. 18-19; Noyan 1956, s. 48; Bayırı 2015, s. 81.

${ }^{61}$ Çanakkale Harekâtı, s. 235; Esenkaya ve Martin 2009, s. 271-272; Özbay 1976, c. I, s. 235-237.

62 Noyan 1956, s. 45; Cebeciyan 2019, s. 80-81.

${ }^{63}$ Çanakkale Acı İlaç, s. 66; Esenkaya 2011, s. 31.

${ }^{64}$ Çanakkale Acı İlaç, s. 66.

65 Özbay 1976, c. I, s. 236-238.
} 
karşısında Albay Hans Kannengiesser hayretini şu ifadelerle dile getirmiştir: "Ben her zaman İngilizleri hijyenik olarak düşünmüşümdür. Oysa Türkler her şeyde daha temizdi. ${ }^{66 "}$

Netice itibariyle Osmanlı Devleti, Balkan harplerinde yaşadığı acı tecrübelerden ders çıkararak temizlik hizmetlerine daha da önem vermiştir. ${ }^{67}$ Ordu lojistik destek bölgesi olan menzil sahasından başlayarak ordu ikmal yolları üzerinde ve cephe gerisinde çeşitli mevkilerde askerin banyo yapabileceği yunaklar, elbise ve eşyaların temizlenebilmesi için de sahra etüvleri merkezleri açılarak askerin temizlenmesi için büyük çaba gösterilmiştir. ${ }^{68}$

\section{SONUÇ}

Çanakkale Muharebelerinin cereyan ettiği Gelibolu yarımadası, içme suyu kaynakları açısından pek de zengin sayılmazdı. Bu bakımdan ordunun içme ve kullanım suyu ihtiyacı karşılanırken zaman zaman büyük sıkıntılar yaşanmışıı. Özellikle havaların ısınmaya başlamasıyla muharebe sahasındaki pınar, çeşme ve derelerin önemli bir kısmı kuruduğundan askerin özellikle temiz içme suyu ihtiyacının karşılanmasında büyük zorluklar yaşanmıştır. Buna rağmen Türkler, harp süresince yarımadanın büyük bölümünü, dolayısıyla da temiz su kaynaklarını elinde tutmayı başarmış ve bu avantajını harbin bitimine kadar muhafaza etmiştir.

Muharebeler esnasinda askerin beden, elbise ve çevre temizliğine de gereken önem verildiğinden yetersiz temizlikten kaynaklanan salgın hastalıkların yayılımı engellendi. Balkan Savaşlarındaki acı tecrübelerden dersler çıkarılmış olmalı ki Türkler, Çanakkale Muharebeleri esnasında temizlik hizmetlerine daha fazla önem verdiler. Harbin ağır ve zorlu koşullarında zaman zaman temizlik hususunda sıkıntılar yaşanmışsa da alınan önlemler ve Türk Sıhhi Teşkilatının çabaları sayesinde orduda zuhur eden bulaşıcı hastalıklar, ordu geneline sirayet etmeden kısa sürede bertaraf edilmiştir.

\footnotetext{
${ }^{66}$ Kannengiesser 2009, s. 256.

${ }^{67}$ Noyan 1956, s. 35.

68 Özbay 1976, c. I, s. 237-238; Esenkaya 2011, s. 32.
} 


\section{KAYNAKLAR}

\section{a. Arşiv Kaynakları}

ATASE Arşivi, BDH, Kls. 1126, Dos. 11, Fih. 7-1.

ATASE Arşivi, BDH, Kls. 1150, Dos. 107, Fih. 6-20.

ATASE Arşivi, BDH, Kls. 1157, Dos. 133, Fih. 1-53.

ATASE Arşivi, BDH, Kls. 1181, Dos. 226, Fih. 44-5, 44-6, 44-7, 44-9.

ATASE Arşivi, BDH, Kls. 3527, Dos. 21, Fih. 29, 29-1.

ATASE Arşivi, BDH, Kls. 3528, Dos. 25, Fih. 2.

ATASE Arşivi, BDH, Kls. 3535, Dos. 56, Fih.7.

ATASE Arşivi, BDH, Kls.1129, Dos. 27, F.2.

BOA, DH.İ.UM, 81/1.

BOA, DH.İ.UM, 93/1.

BOA, DH.İ.UM.EK., 14/80.

BOA, DH.İ.UM.EK., 27/29.

BOA, MV., 205/91.

BOA, BEO, 4296/322159.

BOA, BEO, 4451/333783.

BOA, DH.İ.UM, 93/1.

BOA, DH.İ.UM., 89/1.

BOA, DH.İ.UM.EK., 34/2.

BOA, HR.H..., 37/10.

BOA, HR.SFR., 879/81.

BOA, ŞD., 1249/39.

\section{b. Osmanlıca Kaynaklar}

Piyade Teçhizat1, Harbiye Nezareti Levazımat-1 Umumiye Dairesi, 1327.

Harb Mecmûas1, Y11 1, Say1 3, Kanun-1 Sani 1331.

Harb Mecmûas1, Y1l 1, Sayı. 5, Şubat 1331, s. 71.

Sihhiye Mecmuas1, Y1l 3, Say1 9-10, İstanbul, 1331 (1915).

Sihhiye Mecmuas1, Sayı 11-12, Matbaa-i Bahriye, 1333 (1917).

Muzaffer (Erkân-1 Harbiye Kaymakamı), Harb-i Umumiden Alınan Bazı Malumat ve Tecârübden Seferber Ordularda ve Menzillerde Geri Hidemât Rehberi, Matbaa-i Askeriye, Dersaadet 1339

Abdülkadir Bey 1332, Abdülkadir Bey (Tabip Yüzbaşı), "Fırın ve Çadır Hamamı İle

Tathirat", Sihhiye Mecmuası, Y11 3, S. 7, s. 479

\section{c. Araştırma ve İnceleme Eserleri}

Abdullah Fevzi 2011 Abdullah Fevzi, Çanakkale Cephesinde Bir Müderris: Abdullah Fevzi Efendi, Haz. Ali Osman Koçkuzu, İz Yayıncılık, 2. Baskı, İstanbul. 
Abdülkadir 1332

Altay 2002

Arıkan 2007

Ataksor 2008

Aysal 2015

Başustaoğlu 2016

Bayırı 2015

Borlat 2020

Cebeciyan 2019

Conk 2002

Çalık ve Tepekaya 2006

Ramazan Çalık - Muzaffer Tepekaya, "Birinci Dünya Savaşı Esnasında Anadolu'daki Salgın Hastalıklar ve Ermeniler", Selçuk Üniversitesi Sosyal Bilimler Enstitüsü Dergisi, S. 16, s. 205-228.

Çanakkale Acı İlaç Çanakkale Acı İlaç (18 Mart 1915 - 9 Ocak 1916), Deva Holding, İstanbul 2015.

Ege 2011

Erduran 2015

Esat Paşa 2004

Esenkaya 2014

Abdülkadir, (Tabip Yüzbaşı) "Fırın ve Çadır Hamamı İle Tathirat", Sihhiye Mecmuası, Y11 3, S.7, İstanbul, s. 479-483.

Fahrettin Altay, Çanakkale Hatıraları, (Yay. Haz. Metin Martı), c. 2, Arma Yay., İstanbul.

İbrahim Arıkan, Harp Hatıralarım Bir Mehmetçiğin ÇanakkaleGaliçya-Filistin Cephesi Anıları, Haz: Selman Soydemir ve Abdullah Satun, Timaş Yay., İstanbul.

Halis Ataksor, Çanakkale Raporu, Binbaşı Halis Bey'in Savaş Notları, Haz: S. Serdar Halis Ataksor, Timaş Yay., İstanbul.

Necdet Aysal, "Çanakkale Muharebeleri'nde Sağlık Hizmetleri ve Osmanlı Hilâl-i Ahmer Cemiyetinin Faaliyetleri”, 100'ücü Yllında Çanakkale Zaferi Sempozyumu, İstanbul, s. 10-41.

Ahmet Başustaoğlu, Bir Nefes Sıhhat Tevfik Sağlamın Yaşamı, Türkiye İş Bankası Kültür Yay., İstanbul.

Mehmet Halit Bayırı, Cephe Arkadaşı Çanakkale Cephesi'nde Bir İstanbullu, Yay. Haz. Lokman Erdemir, Timaş Yay., İstanbul.

Barış Borlat, Çanakkale Cephesi'nde İkmal Faaliyetleri 19141916, İstanbul.

Avedis Cebeciyan, Bir Ermeni Subayının Çanakkale ve Doğu Cephesi Günlüğ̈̈ 1914-1918, (Yayına Haz. Rober Koptaş), İstanbul.

Cemil Conk, Çanakkale Hatıraları, (Yay. Haz. Metin Martı), 2. Cilt, Arma Yay., İstanbul.

Abidin Ege, Çanakkale, Irak ve Iran Cephelerinden Harp Günlükleri, Yay. Haz: Celali Yılmaz, Türkiye İş Bankası Kültür Yay., İstanbul.

Behçet Sabit Erduran, Cephedeki Bir Doktorun Gözünden 1915 Baharında Çanakkale, Haz: Tamay Açıkel, Türkiye İş Bankası Kültür Yayınları, İstanbul.

Esat Paşa, Esat Paşa'nın Çanakkale Savaşı Hastıraları, Yay. Haz. İhsan Ilgar ve Nurer Uğurlu, Örgün Yayınevi, İstanbul.

Ahmet Esenkaya, "Çanakkale Cephesi'nde İdari Faaliyetler ve Lojistik Hizmetleri”, Çanakkale Araştırmaları Türk Yıllı̆̆ı, Yıl 12, Sayı 17, s. $45-83$. 


\section{Çanakkale Cephesi'nde Su Temini ve Temizlik Hizmetleri}

Esenkaya 2011

Ahmet Esenkaya, "Çanakkale Muharebelerinde Cephede ve Cephe Dışında Sağlık Hizmetleri”, Çanakkale Araştırmaları Türk Yıllı̆̆l Dergisi, Y11 9, S. 10-11, s. 25-70.

Esenkaya ve Marttin 2009

Ahmet Esenkaya - Volkan Marttin, "Çanakkale Savaşlarında Temizlik”, Temizlik Kitabı, Editörler: Emine Gürsoy Naskali ve Salih Mehmet Arçın, İstanbul, s. 261-273.

Çanakkale Cephesi Genelkurmay Başkanlığı, Birinci Dünya Savaşı Çanakkale Cephesi Harekâtı (Haziran 1914-Ocak 1916), Ankara 2014.

Çanakkale Harekâtı Genelkurmay Başkanlığı, I. Dünya Harbinde Türk Harbi Çanakkale Cephesi Harekâtı, V. Cilt, III. Kitap, Ankara 1980.

Genişol $2014 \quad$ Hüseyin Fehmi Genişol, Çanakkale'den Bağdat'a Esaretten Kurtuluş Savaşına Cephede Sekiz Yll Sekiz Ay (1914-1923), (Yay. Haz. Mustafa Yeni), Türkiye İş Bankası Kültür Yay., İstanbul.

Gözcü 1937 Niyazi İsmet Gözcü, "Umumi Harpte Çanakkale Müdafaası Esnasında Türk Ordusu Sihhi Hizmetleri”, Askeri Sihhiye Mecmuası, Sene 67, Say1 23, s. 77-91.

Hamilton 2006 Ian Hamilton, Gelibolu Hatıraları 1915, Ed.: Ö. Andaç Uğurlu, Örgün Yayınevi, İstanbul.

Hasan Cevdet Bey 2015

Hasan Cevdet Bey’in Çanakkale ve Doğu Cephesi Günlüğü: Klyamet Koptuğunda, Haz.: Mutlu Karakaya, Yeditepe Yay., İstanbul.

İbrahim Naci 2018 İbrahim Naci, Allahaısmarladık Çanakkale Savaşı'nda Bir Şehidin Günlüğ̈̈, Haz. Seyit Ahmet S1lay, Yeditepe Yay., İstanbul.

Kannengiesser Pasha 2015

Hans Kannengiesser Pasha, Çanakkale Cehenneminde 500 Alman, Çev. Ege Çınar Arcan, Doğu Kitabevi, İstanbul.

Kannengiesser 2009 Hans Kannengiesser, Çanakkale'de Türklerle Beraber, Bir Alman Albayın Gözünden Çanakkale, Çev. Mehmet Serez, 1. Bask1, Timaş Yay. İstanbul.

Kütükoğlu 2018 Mübahat S. Kütükoğlu, Osmanlının Sosyo-Kültürel ve İktisadi Yapısı, TTK Yay., Ankara,

Münim Mustafa 2002 Münim Mustafa, Çanakkale ve Kanal Seferi Hatıraları Cepheden Cepheye, (Yay. Haz. Metin Martı), Arma Yay., İstanbul.

Noyan 1956

Abdülkadir Noyan, Son Harplerde Salgın Hastalıklarla Savaşlarım, Ankara Tıp Fakültesi Yay., Ankara.

Noyan 1940 Abdülkadir Noyan, "Harp Salgınları", Askeri Sıhhiye Mecmuast, Sene 69, Sayı 29, s. I-VIII. 
Özbay 1976

Özbay 1976

Özdemir 2010

Özer 2016

Özgen 2011

Safiyyüddin 2019

Schweder 2012

Server Kâmil 2016

Sınmaz Sönmez 2016

Sunata 2008

Tevfik Salim 1935

Yaşar 2001

Zembrzuska 2019
Kemal Özbay, Türk Asker Hekimliği Tarihi ve Asker Hastaneler, c. I, Yörük Basımevi, İstanbul.

Kemal Özbay, Türk Asker Hekimliği Tarihi, c. II, İstanbul Matbaası, İstanbul.

Hikmet Özdemir, Salgın Hastalıklardan Ölümler 1914-1918, TTK Basımevi, Ankara.

Sevilay Özer, "Birinci Dünya Savaşı'nda Osmanlı Devleti'nde Tifüs (Lekeli Humma) Salgını", Belleten, c. LXXX, S. 287, s. 219-260.

Mehmet Sinan Özgen, Bolvadinli Mehmet Sinan Bey'in Harp Hatıraları, Yay. Haz. Servet Avşar, Hasan Babacan, Muharrem Bayar, İstanbul.

Safiyyüddin, Süvari Teğmen Safiyyüddin Efendi'nin Çanakkale ve Kafkas Cephesi Harp Hatıratı, Yay. Haz. Eren Ergül, Yeditepe Yay., İstanbul.

Paul Schweder, Çanakkale Cephesinde Türk Genel Karargahında, Çev.: Eşref Bengi Özbilen, Yedi Tepe Yay., İstanbul.

Server Kâmil (Bakteriyolog), Tip Tarihinde Imtisal Bir Eser Kafkas Cephe-i Harbinde Lekeli Humma, (Yay. Haz. Meriç Aybar \& İbrahim Caner Türk), Arı Sanat Yay., İstanbul.

Cahide Sınmaz Sönmez, Çanakkale Cephesi'nde Sağlık Kuruluşları ve Kızılay Arşiv Belgelerine Göre Hilâl-i Ahmer Cemiyeti'nin Faaliyetleri”, Çanakkale Araştırmaları Türk Ylllı̆gl, Y1l 14, Say1 20, s. 173-192.

İ. Hakkı Sunata, Gelibolu'dan Kafkaslara Birinci Dünya Savaşı Anılarım, (Yay. Haz. Kansu Şarman), Türkiye İş Bankası Kültür Yay., 3. Bask1, İstanbul.

Tevfik Salim (Mütekaid Doktor Tümg.) "Büyük Harbde Kafkas Cephesindeki Sihhi Vaziyete Dair Bir Tetkik", Askeri Местиа, c. VI, Say1 97, s. 487-504.

Okan Yaşar, "Gelibolu Yarımadası Tarihi Milli Parkı (Barış Park1), Yaşanan Sorunlar ve Çözüm Önerileri”, Türk Coğrafya Dergisi, Say1 36, İstanbul, s. 171-201.

Wanda Zembrzuska,Muhabirimiz Çanakkale Cephesinden Bildiriyor! Miralay Mustafa Kemal Bey'le Buluşma, Ağustos 1915, Çeviri, sunuş ve notlar: Hüseyin Mevsim, Kitap Yayınevi, İstanbul. 


\section{Çanakkale Cephesi'nde Su Temini ve Temizlik Hizmetleri}

\section{SUMMARY}

Meeting the water demand, taking proper hygienic measures for soldiers' clothes, and ensuring personal hygiene during wartime are within the dimension of military logistics. Thus, lack of clean drinking water in the combat zone or insufficient measures for soldiers' hygiene can lead to epidemics within the army. In such a case, troops may face an epidemic even before meeting the enemy. Therefore, it is crucial to provide utility water necessary for clean drinking water and proper hygiene for armies in the combat zone during war.

This study discusses the drinking water demand and hygiene activities in the Turkish army during the battles of Gallipoli. The Gallipoli peninsula, where the battles occurred, was not particularly rich in clean drinking water sources. Therefore, it was impossible to meet the water demand of a large army with the available drinking water sources on the peninsula. Even though the combat zone was intertwined with the sea, the seawater could not be used as drinking water because, at the time, the Ottoman Empire did not have the technology to purify the seawater. The seawater could have been used for personal hygiene and cleaning of sheltering areas and the environment. However, the seawater could not be used as utility water because no conveyance system that would have carried the seawater to the combat zone could have been installed during the battles. Thus, both the army's drinking water and utility water demands were met from the fountains, springs, wells, and streams located in the combat zone.

The purity of water sources from which the drinking water demand of the army was met was another major problem during the battles. Because polluted water leaked into the drinking water sources, an epidemic could have been created among the soldiers. In this regard, the Turkish Ministry of Health examined the water sources in the combat zone and tried to prevent the use of polluted water sources. Water sources that were not convenient for use were destroyed and made inconsumable, or soldiers were warned about this issue by hanging warning boards where the source was located. Polluted water sources were identified, and preventive measures were used to discourage the use of water in these sources, and there was an attempt to rehabilitate the polluted water resources.

At first, Turkish people did not take a measure to meet the water demand of the army at the Gallipoli front. Therefore, the majority of the water demand was met with fountains, springs, wells built by the locals, and streams. However, the drinking water sources in the area were not enough to meet the needs of a large army. Especially during the summer, when the available water sources began to dry up, the army faced great difficulties with their water supply. When the weather started to warm up, the Ottoman army corps of engineers drilled new artesian wells in the stream beds to meet the army's increased water demand.

Moreover, to have easy access to the water and meet the water demand of the support services units such as kitchens, latrines, and hospitals, all of which have a very high water demand, were established in the stream beds. Despite these measures, in a region like the Gallipoli peninsula, a very narrow area and with insufficient water sources, it was impossible to seamlessly meet the water demand of an army of hundreds of 
thousands of soldiers. Since the Turkish army managed to hold the majority of the peninsula and the clean water sources, they maintained the advantage of access to drinking water until the end of the war. 